\title{
Studies on Aerobic Bacterial Flora Associated with Postpartum Subclinical Endometritis in Crossbred Dairy Cows
}

\author{
A. Sahadev ${ }^{*}$, A. Krishnaswamy ${ }^{1}$, G. Sudha ${ }^{1}$, M. Narayana Bhat ${ }^{2}$, \\ M. Narayanaswamy ${ }^{3}$, B. N. Nagaraja ${ }^{4}$ and Suryanarayana ${ }^{5}$ \\ ${ }^{1}$ Department of Veterinary Gynaecology and Obstetrics, ${ }^{2}$ Department of Teaching Veterinary \\ Clinical Complex, ${ }^{3}$ Department of Veterinary Physiology, ${ }^{4}$ Department of Veterinary Surgery, \\ ${ }^{5}$ Department of Clinical Medicine, Veterinary College, KVAFSU, Hebbal, \\ Bangalore - 560 024, Karnataka, India \\ *Corresponding author
}

A B S T R A C T

A clinical study was conducted with the objective to isolate and identify the uterine

Keywords

Subclinical

endometritis,

Day's postpartum,

Aerobic bacteria,

Crossbred dairy

cows.

Article Info

Accepted:

26 June 2017

Available Online:

10 July 2017 aerobic bacteria in crossbred dairy cows with postpartum subclinical endometritis (SCE). One hundred and ninety four recently calved cows from different organized dairy farms in and around the city of Bangalore were screened for SCE by endometrial cytology using cytobrush technique on 35 day postpartum (dpp) from the cows. Uterine samples were collected from the cows found positive (98) for SCE using endometrial cytobrush for aerobic bacterial culture. Either single isolate (42.16 per cent) or mixed isolates ( 57.83 per cent) were isolated from the uterus in 83 out of 98 cows with SCE. The most common single isolate observed was Escherichia coli (45.71 per cent) in 16 out of 35 cows followed by Staphylococcus (42.86 per cent), Proteus spp. and Enterobacter sp. (5.71 per cent). Whereas, E. coli + Staphylococcus $s p$. were isolated as mixed isolates in 32 (66.67 per cent) out of 48 cows followed by $E$. Coli + Proteus in 11 cows, E. coli + Staphylococcus and E. coli + Enterobacter sp. in one cow each besides three cows $(6.25$ per cent) with more than three different isolates. In the present study, E. coli was the most frequently isolated aerobic bacteria either as single isolate or as mixed isolate with other aerobic bacteria in crossbred dairy cows at $35 \mathrm{dpp}$ with SCE.

\section{Introduction}

In dairy farming the period immediately after parturition in cows, commonly referred to as the postpartum period is one of the critical stages that affect the production. The greatest impact on health and productivity is associated with microbial contamination of the uterine lumen after parturition. About 80 to 90 per cent of dairy cows have a bacterial contamination of the uterine lumen in the first two weeks after parturition (Sheldon et al., 2009) with subsequent clearance and recontamination. In majority of the cows, the bacterial contamination is mostly resolved by uterine involution, through passage of lochia and due to the mobilization of immune defense systems. However, failure to resolve the contamination can compromise uterine function and persistence of pathogenic bacteria during the postpartum causing uterine infection in 10 to 20 per cent of postpartum dairy cattle (Gilbert et al., 1998; LeBlanc et al., 2002; Sheldon et al., 2009). Such uterine infections are associated with tissue damage, delayed uterine involution, disruption of 
endometrial function and altered ovarian cycles (Sheldon et al., 2002a; Herath et al., 2006).

Uterine infections cause infertility in acute cases and subfertility in chronic cases. Consequently, uterine infection in cows will reduce conception rate, increase calving to conception interval and contribute for increased culling rate (Borsberry and Dobson, 1989; Herath et al., 2006; Sheldon et al., 2009). Among the various bacteria that cause uterine infection the most common bacteria include Escherichia coli, Arcanobacterium pyogenes, Fusobacterium necrophorum and Prevotella sp. (Griffin et al., 1974; Sheldon et al., 2002b) and are acquired from the feces and fecal contamination of the coat, bedding and environment.

The presence of bacterial pathogens in the uterus of cows suffering from SCE has been attributed to various factors during and after calving (Markusfeld, 1987; Hussain et al., 1990; Kim and Kang, 2003). In view of this, a clinical study was designed with the objective to determine common aerobic pathogens associated with postpartum subclinical endometritis in crossbred dairy cows.

\section{Materials and Methods}

The study was conducted on a total of 194 recently calved crossbred Holstein Friesian and Jersey cows maintained in five organized dairy farms in and around the city of Bangalore. The herd size ranged from 37 to 115 , the age of the cows ranged from 3.6 to 12 years, with parity from one to six and the average 305-day milk yield of previous lactation ranged from 2440 to 7930 liters. In all the dairy farms, the cows were allowed for grazing and housed in tie stalls with concrete floor or stone slabs. Rations were based on ragi straw and green fodder/silage and supplemented with concentrate feeds and mineral mixture.
All the cows on day 35 postpartum which did not exhibit any evidence of clinical endometritis on the basis of history, physical examination or vaginoscopy were subjected for endometrial cytological (EC) procedures to identify whether the cow was free from endometritis or was suffering from SCE. The endometrial cytology was studied using the samples obtained by cytobrush technique as per the procedures described by Baranski et $a l$. , (2012). The samples were obtained using ready to use sterilized cytobrushes which were procured either from Mintub, Germany or from Nasco, USA. The sample collected was utilized for both endometrial cytology studies.

The cytobrush containing the endometrial sample was then gently rolled on to a clean grease fee microscopic slide. The smear was air dried, fixed with methanol and stained with Geimsa stain. The smears were examined first under 400X and then under $1000 x$ to determine the proportion of polymorph nuclear neutrophils. A total of 300 cells excluding RBCs were counted and the proportion of PMNs among was recorded. Each slide was read by two persons and the average of the readings was considered. A cow was considered to be suffering from $\mathrm{SCE}$, if the proportion of PMNs was greater than 10 per cent as suggested by Kasimanickam et al., (2004) and less than 10 per cent PMNs were considered to be free from SCE.

\section{Bacteriological studies}

All the cows diagnosed positive for SCE were subjected to bacterial evaluation of the uterine secretions using a sterile cytobrush and the technique of obtaining the sample was similar to the technique described earlier for studies on endometrial cytology. The cytobrush samples were immediately dipped into sterile tubes containing the brain heart infusion broth 
and transported to the laboratory within 2 to 3 hours and kept in an incubator for 24 hours at $37^{\circ} \mathrm{C}$. The BHI broth was then checked for the turbidity and using a sterilized loop the broth culture was streaked onto BHI and selective media viz., MacConkey agar and Mannitol salt agar and incubated for 24 hours at $37{ }^{\circ} \mathrm{C}$. The plates were examined for bacterial growth. The colonies in MacConkey agar obtained after primary inoculation were inoculated to selective media, Eosin Methylene Blue agar. The cultures were examined followed by detailed study of colony characteristics including the morphological and biochemical properties as per Cruickshank et al., (1980). Cultures were preserved in culture tubes and kept at 4-5C for subsequent identification.

\section{Results and Discussion}

The spectrum and frequency of aerobic bacterial flora recovered from the uterus of cows with SCE is presented in table 1. Either a single isolate or mixed isolates were isolated from the uterus of 83 out of 98 cows. Mixed colonies in 57.83 per cent and single isolates in 42.16 per cent of cows with SCE were cultured. The most common single aerobic bacterial isolate cultured from cows with SCE in the present study was Escherichia coli in 45.71 per cent. The other most commonly recovered bacterial isolates were Staphylococcus (42.86 per cent), Proteus spp. and Enterobacterspp. (5.71 per cent) each.

Among the mixed isolates, E. coli and Staphylococcus spp. were isolated in 32/48 cows (66.67 per cent). A mixed culture of $E$. coli and Proteus was obtained in 11 other cows, while E. coli and Staphylococcus and E. coli and Enterobacter $s p$. were cultured in one cow each. In three cows (6.25 per cent), more than three different isolates were cultured. Anatomical barriers such as the vulva, vestibule, vagina and cervix function as that protect the uterus from bacterial contamination during pregnancy in dairy cows. During parturition, relaxation of the vulva and cervical dilation allow for the entry of bacteria into the uterus (Sheldon, 2004; Azawi, 2008) and hence, bacterial contamination of the uterus postpartum is common. It has been demonstrated that 33 per cent of dairy cows had positive bacterial cultures during the first week after calving and by the second week, the number of positive cases had increased to 44 per cent (Fredriksson et al., 1985). Sheldon and Dobson, (2004) have used more sensitive culturing technique, and observed that 80 to 100 per cent of the cows had during the first two weeks postpartum despite complications during calving. The prevalence and species of the bacteria is reported to gradually decrease along with postpartum days (Foldi et al., 2006). Thus, the presence of bacteria is sporadic on day 28 to 35 days after calving and many authors opined that the uterine cavity should be sterile thereafter (Paisley, 1986; Hussain, 1989). Therefore, isolation of pathogenic bacteria during the late postpartum period is highly suggestive of endometrial inflammation and when such infection is not associated with clinical signs, it is highly possible that the cow is suffering from SCE.

In the present study, 194 cows which did not exhibit any of the clinical signs suggestive of endometrial inflammation were examined for the presence of aerobic bacteria in the uterus on day 35 postpartum. Pathogenic aerobes were isolated in 83 (42.78 per cent) cows examined for the evidence of SCE. The entire83 cows positive for the presence of pathogenic bacteria in the uterus were also positive for SCE when examined using EC technique. However, aerobic bacteria could not be isolated in another 15 cows which had been diagnosed as cases of SCE by EC studies. Thus, aerobic bacteria could be isolated in 84.69 per cent of cows diagnosed as cases of SCE using EC technique. 
Table.1 Frequency of isolation of single and mixed aerobic bacterial colonies from the uterus at 35 dpp of cows with SCE (N=83)

\begin{tabular}{|l|c|c|}
\hline Type of bacterial culture & No. of aerobic bacterial isolates & Percentage \\
\hline Single isolate & $\mathbf{3 5}$ & $\mathbf{4 2 . 1 6}$ \\
\hline E. coli & 16 & $45.72 \%$ \\
\hline Staphylococcus & 15 & $42.86 \%$ \\
\hline Proteus & 2 & $5.71 \%$ \\
\hline Enterobacter & 2 & $5.71 \%$ \\
\hline Mixed isolate & $\mathbf{4 8}$ & $\mathbf{5 7 . 8 3}$ \\
\hline E. coli + Proteus & 11 & $22.92 \%$ \\
\hline E. coli + Staphylococcus & 32 & $66.67 \%$ \\
\hline E. coli + Enterobacter & 01 & $2.08 \%$ \\
\hline Proteus + Staphylococcus & 01 & $2.08 \%$ \\
\hline More than 3 isolates & 03 & $6.25 \%$ \\
\hline Total & $\mathbf{8 3}$ & $\mathbf{1 0 0}$ \\
\hline
\end{tabular}

Further, a greater proportion of SCE was associated with mixed bacterial contamination of the uterus (57.83 per cent), while single isolates was recovered in 42.10 per cent of cows. E. coli and S. aureus were the predominant aerobic bacteria isolated in cows with SCE. The other pathogenic aerobic bacteria isolated in a fewer number of cows were Proteus spp. and Enterobacter. Singla et al., (2004) have similarly reported that microorganisms isolated from uterine swabs of cows with SCE were mainly E. coli, $S$. aureus and Proteus spp., whereas Streptococcus spp., Klebsiella spp., Psuedomonas spp., A. pyogenes and Bacillus spp. were less frequently isolated. Barman et al., (2013) in a recent study reported that non lactose fermenting organisms belonging to family Enterobacteriaceae were the most common isolates in cows with SCE. The other common bacteria isolated were E. coli, Streptococcus, Staphylococcus spp., Pseudomonas spp. and Bacillus spp.

Although, the postpartum uterus makes a continuous effort to eliminate bacteria which have gained entry into the uterus at the time of parturition, the reasons for the persistence of some pathogenic bacteria during the late postpartum period has not been explained properly in the literature. It is possible that some cows eliminate the bacteria contaminating the uterus during the early postpartum period only to be re-contaminated later with one or other pathogenic bacteria. On the other hand, it is also possible that the uterus of some cows fail to eliminate all the bacteria acquired during the parturition resulting in persistence of bacteria during the late postpartum period. This situation could probably be attributed to either weak uterine defense mechanism or poor immune status of the cow. Other factors such as, poor hygiene and stress of housing and management (Kim and Kang, 2003) could also play a role in development of SCE during the late postpartum period.

In the present study, no pathogenic aerobic bacteria could be isolated in as many as 15 cows which were positive for SCE on the basis of EC studies. This may not mean the absence of clinical endometritis as a number of other anaerobic bacteria or viruses could be associated with SCE. The present study clearly found that there was a high degree of correlation between diagnoses made from the studies on EC with bacteriology of the uterus. 
However, bacteriological studies to diagnose SCE could be difficult and because of its high correlation with EC, the latter could be the choice of technique because of its simplicity under field conditions.

\section{Acknowledgement}

The author acknowledges the Karnataka Veterinary, Animal and Fisheries Sciences University, Bidar for providing deputation facility and financial support during the period of study. This is part of the Ph.D. thesis submitted by the first author to KVAFSU.

\section{References}

Azawi, O. I. 2008. Post-partam uterine infection in cattle. Anim. Reprod. Sci., 105(3-4):187-208.

Barman, P., Yadav, M.C., Bangthai, A. and Kumar, H. 2013. Antibiogram of bacteria isolated from bovine endometritis. Vet. Res. International, 1: 20-24.

Borsberry, S. and Dobson, H. 1989.Periparturient diseases and their effect on reproductive performance in five dairy herds.Vet. Rec., 124(9):2179.

Foldi, J., Kulcsar, M., Pecsi, A., Huyghe, B., Desa, C., Lohuis, J.A., Cox, P. and Huszenicza, G. 2006.Bacterial complications of postpartum uterine involution in cattle. Anim. Reprod. Sci., 96: 265-281.

Fedriksson, G., Kindahl, H., Sandstedt, K. and Edqvist, L.E. 1985. Intrauterine bacterial findings and release of PGF2 alpha in the postpartum dairy cow. Vet. Med., 32:368-380.

Gilbert, R. O., Shin, S. T., Guard, C. L. and Erb, H. N. 1998.Incidence of endometritis and effects on reproductive performance of dairy cows.
Theriogenology, 49:251.

Griffin, J., Hartigan, P. and Nunn, W. 1974.Infection patterns and endometritis during the first seven weeks postpartum. Theriogenology, 1(3):91-105.

Herath, S., Fischer, D.P., Werling, D., Williams, E. J., Lilly, S. T., Dobson, H., Bryant, C. E., Sheldon, I. M.2006.Expression and function of Toll-like receptor 4 in the endometrial cells of the uterus. Endocrinol., 147: $562-570$.

Hussain, A. M. 1989. Bovine uterine defense mechanisms: a review. Zentralbl Veterinarmed, 36:641-51.

Hussain, A. M., Daniel, R. C. W. andO'boyle, D. 1990. Post-partum uterine flora following normal and abnormal puerperium in cows. Theriogenology, 34: 291-302.

Kim, I. H. And Kang, H. G. 2003. Risk factors for postpartum endometritis and the effect of endometritis on reproductive performance in dairy cows in Korea. J. Reprod. Dev., 49(6):48591.

Leblanc, S. J., Duffield, T. F., Leslie, K. E., Bateman, K. G., Keefe, G. P., Walton, J. S. and Johnson, W. H. 2002. Defining and diagnosing postpartum clinical endometritis and its impact on reproductive performance in dairy cows. J. Dairy Sci., 85:2223-2236.

Markusfeld, O. 1987. Periparturient traits in seven high dairy herds. Incidence rates, association with parity and interrelationships among traits. J. Dairy Sci., 70: 158-166.

Moges, N. and Jebar, A. 2012. Prevalence of subclinical endometritis and its effect on pregnancy in crossbred dairy cows in Gonder. J. Reprod. Fertil, 3(2): 26-31.

Paisley, L. G., Mickelsen, W. D. and Anderson, P. B. 1986. Mechanisms and therapy for retained fetal membranes and uterine infections of cow: A review. 
Theriogenology, 25: 353-381.

Sheldon, I. M. and Dobson, H. 2004.Postpartum uterine health in cattle. Anim. Reprod. Sci., 82: 295-306.

Sheldon, I. M., Noakes, D. E., Rycroft, A. N., Pfeiffer, D. U. and Dobson, H. 2002a. Influence of uterine bacterial contamination after parturition on ovarian dominant follicle selection and follicle growth and function in cattle. Reproduction, 123:837-845.

Sheldon, I., Noakes, D., Rycroft, A. and Dobson, H. 2002b. Effect of postpartum manual examination of the vagina on uterine bacterial contamination in cows. Vet. Rec., 151: 531-534.

Sheldon, I. M., Price, S. B., Cronin, J., Gilbert, R. O. and Gadsby, J. E. 2009.
Mechanisms of infertility associated with clinical and subclinical endometritis in high producing dairy cattle. Reprod. Dom. Anim., 44 (3): 1-9.

Sheldon, I. M., Rycroft, A. N. and Zhon, C. 2004.Association between postpartum pyrexia and uterine bacterial infection in dairy cattle. Vet. Rec., 154: 289-293.

Singla, P., Singh, J., Dhaliwal, G.S. and Kumar, A. 2004.Effect of post AI intrauterine treatment with $\mathrm{E}$. coli lipopolysaccharide and autologous serum on characteristics of cervicovaginal mucous in subclinical endometritic cows. Ind. J. Anim. Reprod., 25: 55-57.

\section{How to cite this article:}

Sahadev, A., A. Krishnaswamy, G. Sudha, M. Narayana Bhat, M. Narayanaswamy, B.N. Nagaraja and Suryanarayana. 2017. Studies on Aerobic Bacterial Flora Associated with Postpartum Subclinical Endometritis in Crossbred Dairy Cows. Int.J.Curr.Microbiol.App.Sci. 6(7): 2352-2357. doi: https://doi.org/10.20546/ijcmas.2017.607.336 